\title{
A Survey Of Personal Hurdles Contributing To Failures Of Rural Entrepreneurship: Economic Implications For Owner-Managers
}

Albert Tchey Agbenyegah, Durban University of Technology, South Africa Bongani Innocent Dlamini, Durban University of Technology, South Africa

\begin{abstract}
This study seeks to explore with keen understanding of personal hurdles as revealed by owner-managers from two rural settings of the Northern Cape Province (NCP). The study focuses on personal hurdles that according to literature contributes to the growing failure of entrepreneurial activities. Personal hurdles were assessed using "Statistical Package for the Social Science" (SPSS). A survey method is utilized in gathering primary dataset, descriptive analysis and frequency tables were used to assess all the basic variables including the personal hurdles of owner-managers. Factor analysis was utilized as a determinant of personal hurdles. Formulated hypotheses for the study were tested by the inferential statistic of Analysis of Variance (ANOVA). Relationships between dependent (rural entrepreneurial failures) and independent variables (resources, information and infrastructure gaps) were ascertained through the Pearson Correlation techniques. The study revealed that the resource gaps affect rural entrepreneurial failure (REF) On the other hand, information and infrastructure do not have significant effect on REF. A moderate positive linear correlation between resource gap and REF was detected. Furthermore, there is a low positive linear correlation between REF and the two independent variables (information and infrastructure gaps) were detected.
\end{abstract}

Keywords: Owner-Managers; Personal Hurdles; Entrepreneurial Activities; Economic Implications; Northern Cape Province

\section{INTRODUCTION}

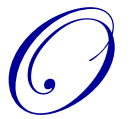

ver the years entrepreneurship in general and in particular rural entrepreneurship has emerged as a resounding research area. In line with this study, not only has rural entrepreneurship been isolated but it also lost its momentum in the academia. Drawing from the declining rural economic outlook in terms of rising decay in job opportunities, it seems timeous to present this rural survey.

Entrepreneurial activities and small businesses are the main triggers of communities' socio-economic well-being. Through entrepreneurial activities, other economic activities are stimulated, jobs are created, poverty is reduced and there is rising standard of living at community levels (Van Vuuren \& Groenewald, 2007). By all accounts, entrepreneurial activities drives economic prosperity and employment opportunities (European Commission, 2013). In spite of its complexity, entrepreneurship continue to be of maximum assistance to communities since its positive outcomes is known to drive and support socio-economic outlook of community engagements (Bosworth, 2012; Duarte \& Diniz, 2011).

Globally, entrepreneurial activities have received much attention and support through government policies. For instance, in Europe the policy of "Think Small First" was formulated with directives of solving the acute problems of lack of financial assistance to owner-managers of small businesses (Karjalainen \& Kemppainen, 2008). Elsewhere in Singapore, the government introduced the "SME 211" initiatives as a 10 years strategic initiatives to enhance the competitive positions of small businesses in market places. Other African countries also instituted policies to help entrepreneurial activities in their countries. In Ghana the government introduced the Private Sector Advisory Group 
(PSAG) as an organ to provide financial assistance to small businesses and to acquire operational equipment for business (Abor \& Quartey, 2010). In order to increase growth among small businesses and create sustainable employment, the South African government created an enabling climate for entrepreneurial activities through The White Paper on Small Businesses (Republic of South Africa, 2005). Further policies were initiated in the form of policy interventions for reskilling, upgrade individuals' technological skills, and build efficiency and to reduce existing remoteness of small businesses to fast track networking among the owner-managers of small businesses (Njiro \& Compagnoni, 2010). Besides, the Integrated Small Enterprise Development Strategy (ISEDS) was established to assist small businesses access needy funds and to provide non-financial assistance, establish network for products and services (Wink, 2008).

In spite of government attempts to assist entrepreneurial activities, the owner-managers of small businesses are unable to provide sufficient economic development (Cant \& Wiid, 2013) instead the failure rate of entrepreneurship has become a resounding rural realities. Unemployment increases with growing socio-economic burdens on governments organisations such as the Department of Social Development which is responsible to provide social needs to the citizens. The initial objectives of entrepreneurial activities and the small business sector to create job opportunities and reduce poverty worsen in communities. Several studies have cited immeasurable hurdles including personal as the causes of the failure of small businesses not only in South Africa but also in developing countries (Brink \& Cant, 2003, Fatoki, 2011, Agbenyegah, 2013). However, this survey only concentrates on personal hurdles of entrepreneurial activities and small businesses as defined.

The study adopts the definition of small businesses as stated in the Amended National Small Business Act 102 of 2004. Similarly, entrepreneurial activities are operationalized and used in this survey as human tasks by prospective individual(s) that are characterized as a profit-making opportunities and associated risks with the likelihood of establishing new ventures to create job opportunities and creating economic growth due to new market exploitations. Throughout this study entrepreneurial activities and small businesses are used interchangeably with similar meanings. Owner-managers as used in the study means human actions that initiates the formation of new entrepreneurial activities and associated risks, play pivotal role in daily management alone or assisted by family member (s). The survey is aimed at exploring and analyzing owner-managers' perspectives regarding the personal hurdles as contributors to the growing decline of rural entrepreneurial activities (REA) of South Africa.

Despite the enormous contributions through entrepreneurial activities, small businesses in South Africa is faced with increasingly high failure. The questions continue to arise as to how personal hurdles affect entrepreneurial activities in rural areas. For answers to this question, this study is therefore designed to explore personal hurdles that according to literature impede entrepreneurial activities in rural areas. In addition, the study will advance insights into how educational achievements at district levels impact on personal hurdles and entrepreneurial activities. This according to the author, will add more understanding to the role of demographic variables within existing literature on rural entrepreneurial failure.

\section{Operationalization of Hurdles as Used in the Study}

According to the Cambridge Advanced Learners' Dictionary (4th edition), hurdles indicates specific difficulties or problems that need to be fixed prior to reaching any form of progress. Based on this meaning, hurdles can be applied as the closest analogues to related concepts of barriers and challenges. For the purpose of this study, hurdle is defined as any form of impediments that in various ways demonstrate stumbling block to sustainable entrepreneurial activities. Given these definitions, the study uses hurdles to represent any form of activities that constraints entrepreneurial activities and small business operations to be sustained, grow and create job opportunities. Specifically, personal hurdles as used in the study are those activities by human, individuals or groups that becomes a severe challenge to operating successful business thus creating possible failure.

\section{THEORIES OF BUSINESS FAILURE}

Several definitions of business failures have been documented. Yet, there is lack of single definition of what business failure means (Gitman, 2009; Rogoff, Lee \& Suh, 2004). Business failure is a phenomenon that unearthed series of academic disagreements among researchers. Different measurements are used to find its actual meaning and definition 
but to no success. Others are of the view that business failure denotes credit losses, bankruptcy, subjective or economic failure (Gitman, 2009; Zakharakis, Meyer \& De Castro, 1999; Lussier, 1996). The inability of owner-managers to attain set profitable margins and stated objectives are at times cited as the central indicators of business failure. In addition, it is quite easy to measure firm profitability in contrast to other related indices. This study is based on the three themes of business failures namely the inability to access resources and opportunities, the life cycle of the business and its state of liabilities and the business environment (Hisrich \& Peters, 2002; Nieman, Hough \& Niewenhuizen, 2003). The author of this study believe that business resources are vital organs to the survival of rural entrepreneurship where it is uneasy to access outside resources due to lack of adequate infrastructure. Armstrong and Shimizu (2007) opine that resources such as capabilities, general business assets, organizational processes, firms' attributes, information and knowledge are critical to the growth and survival of businesses. The three themes of business failure enable the author critical insights into business failure taking into account the associated hurdles which are the products of business failures. It can therefore be concluded that the moment owner-managers are unable to access any of the three themes, there is eminent threat to exceptionally high business failure. At the heart of business failure according to the three themes is the inability by owner-managers to satisfactorily access resources for business growth and survival.

This study is keen to understand small business failure. Prior studies have led to further understanding of high failure rates of small business failures (Deakins \& Freel, 1998; Temtime \& Pansiri, 2004). As such, the main reasons for entrepreneurial failure is vital in assisting government to become aware of the issues in this regard (Stokes \& Blackburn, 2002). In another study Penrose (1980) argued that at the heart of entrepreneurial activities are the individuals' abilities to discover business opportunities within the immediate environment. In line with this definition, it is fitting to explain rural entrepreneurial failure as the inability of owner-managers to identify viable business opportunities to become more innovative within the dynamics of a robust competitive business climate. Inability by owner-managers to identify business opportunities to make changes to existing products and services lead to business failure among other factors as competitors take over the larger market shares. Drawing from these definitions, this study used business failure and entrepreneurial failure interchangeably.

\section{Rural Entrepreneurship}

In general, entrepreneurship relative to rural small businesses in particular continue to play critical role in marginalized communities. Hence, in the words of Barmon and Chakraborty (2013), entrepreneurship is very instrumental in rural development initiatives. The desire to pursue entrepreneurial activities among rural communities is exceedingly a game changing activities in solving socio-economic problems of poverty, unemployment and underutilization of rural resources (Saxena, 2012). However, in global terms, rural areas area faced with difficulties contrary to urban areas (Brown \& Schafft, 2011). A sentiment echoed by Durr, Lyons and Lichtenstein (2000) that given the prevailing situations there are more opportunities in urban areas than the rural areas. Some of the outstanding areas of concern include the employees' number and businesses' size. Studies have shown that rural businesses tend to be small, insignificant volumes of employees, and lack the requisite services (Mochrie \& Galloway, 2004; Smallbone, North, Baldock \& Ekanem, 2002). These problems can further be explained as rural areas are under unceasing threats of acute shortages of basic infrastructure including lack of clean water and electricity (Werlen, 2007). According to Diochon (2003), the persistent lack of infrastructure in communities is another drawback to business operations in rural areas. Infrastructure deficiencies, according to Frederick (2007), further fuel the testimony to ongoing deficiency of rural entrepreneurship. This is true because through social networks, more elements of infrastructure decay continue to surface in the form of additional resources shortages.

Rural entrepreneurship is high on the agenda of several countries in global contexts; thus the concept of entrepreneurship is broadly recognized as the primary driver of rural development initiatives (Ferrao \& Lopes, 2004). Across Europe, REA is known to propel economic growth (The EU Rural Review, 2011). Further survey alluded to this sentiment that in rural Vietnam, the owner-managers of small businesses are the hub of socio-economic agent (Benedikker, Waibel \& Birtel, 2013). REA according to this study depends on the immediate surroundings for resources to operate businesses. This is further portrayed in several surveys. For instance, Duarte and Diniz (2011) confirm that entrepreneurial activities does not only to promote communities but also act as vital stimulants to socioeconomic well-being. Others are of the opinion that rural entrepreneurship serves as a vital strategic force that is 
proficient of limiting the growing rural depopulation (Petrin \& Gannon, 1997). According to North and Smallbone (2006), it can be disputed that there is the pressing need for strategic means to enhance REA.

Entrepreneurship is central to the creation of new businesses which impact positively on employment opportunities and social welfare in rural areas (Labrianidis, 2006; Chun \& Watanabe, 2012). Besides through entrepreneurship, several recreational facilities including the tourism sector and product quality is changed (Stathopoulou, Psaltopoulous, and Skuras, 2004). There has been sufficient development in rural areas in terms of economic and other innovative activities. According to Fuller-Love, Midmore, and Thomas, (2006), Vaillant and Lafuente (2007), there is ongoing rural economic development and clear signs of innovation in rural areas due to entrepreneurial activities. Other researchers further indicate that entrepreneurship plays pivotal role in business formation and also the expansion of existing ones in developing rural areas (Baumgartner, Schulz \& Seidl, 2013).

\section{CHARACTERISTICS OF RURAL ENTREPRENEURIAL ACTIVITIES (REA)}

Generally, the concept of entrepreneurship dates as far back to Schumpeter's era in 1934. Schumpeter's theories are in line with the socio economic development by owner-managers through entrepreneurial activities which serves as the direct aftermaths of industry innovations. According to Wortman (1990), scientific survey into entrepreneurial activities surfaced in 1980s as its immense contributions to rural development became a public knowledge (Vaillant \& Lafuente, 2007; Fuller-Love et al., 2006). The general interest in entrepreneurship grows as it was discovered that its activities leads to new business formation, better avenues to create jobs, future predictor of investment opportunities that nurtures socio-economic well-being of rural communities' well-being (Chun \& Watanabe, 2012; Labrianidis, 2006). Given all these socio-economic theories, it is surprising that till today, entrepreneurship lack consensus (Gideon, 2012).

In line with global standards, REA may entails setting up industries in rural areas (Ahamad \& Pandey, 2015; Korsgaard $\&$ Muller, 2015). This implies that rural entrepreneurship centers on utilization of localized resources that are found in informal settings of the economy. As such, REA include artisans, pretty traders and street vendors. Several academia alluded to the fact that rural entrepreneurship is about growing utilization of rural resources (Saxena, 2012). However, scientific studies support the notion that not much differences exist between rural and urban businesses as well as the characteristics of owner-managers of rural businesses (Colette \& McElwee, 2014). It is eminent therefore that REA is characterized by using more rural resources as well as employ the services of rural human capital (Bad, Patel, Patel \& Tare, 2013). Another scientific revelation agrees with sentiments that rural entrepreneurship forms part of the localized economy and as key contributor to employment (Meccheri \& Pelloni, 2006).

However, further survey by Kalantaridis and Bika (2011) portrays rural areas to be constrained as entrepreneurs are unable to become innovative. According to the survey, other impediments including market size limitations, insufficient resources, slow decrease in market dynamics and poor infrastructure among others are some of striking features of rural communities. The nature of these critical shortages in operating entrepreneurship, implies that establishing rural businesses is unlikely to generate the expected benefits instead of possible failure. Several scientific works alluded to the fact even though rural owner-managers are able to manage with the least available resources (Siemens, 2010; Meccheri \& Pelloni, 2006; Aldrich \& Martinez, 2001), rural communities are faced with diverse problems of lack of employment, inability to access public amenities including credible education and health facilities (Bosworth, 2012; Lehmann, Dieleman \& Martineau, 2008).

\section{Empirical Evidence of Small Business Failures}

Research indicates that the developed and developing countries largely depends on entrepreneurial activities and small businesses to access jobs and employment, generate income and decrease rising poverty levels (Cravo, Gourlay \& Becker, 2012; Ayyagari, Demirguc-Kunt \& Maksimovic, 2011). In attempts to encourage and stimulate entrepreneurial activities, the South African government stressed the need to assist small businesses by offering financial and nonfinancial support. These programs were bolstered through the enactment of various policy frameworks and by the establishment of organisations such as the Department of Trade and Industries (DTI). The main focus areas of the DTI was to coordinate and implement different supporting plans to offer assistance to small businesses. Other establishments by the government include The Small Enterprises Development Agency (SEDA), the Youth 
Development Agency, The South African Micro Apex Fund, the National Empowerment Fund and the Industrial Development Corporation (IDC) (White Paper, 1995).

In spite of the overwhelming assistance by the government, entrepreneurial activities over the years displayed high failure rates. In global context, small businesses are marred by increasingly high failures. For instance, in the developed countries such as USA, UK and Australia, the small business sectors experiences an exceptionally high failure rates of approximately $80 \%$ to $90 \%$ during the first 10 years. Similarly, across the developing countries including Malaysia and Pakistan, there is equally high lack of successful entrepreneurial activities. An estimate of $60 \%$ and $90 \%$ to $95 \%$ of the small business failed (Ahmad \& Seet, 2009; Khalique, Isa, Shaari \& Abdul, 2011). Fatoki and Asah (2011) add that in South Africa, owner-managers of small businesses are faced with high failure rates of $75 \%$. In another study, Von Broembsen, Wood and Herrington (2005) affirm that roughly $75 \%$ of the small businesses in South Africa are unable to become established firms. The study continued the inability of small businesses to survive beyond 4 years in contrast to other countries (Von Broembsen et al., 2005).

\section{ECONOMIC SIGNIFICANCE OF THE STUDY}

Given the present economic climate of growing unemployment and other social ills, this survey is pivotal to understand rural communities and their entrepreneurial requirements for economic growth to sustain rural entrepreneurial activities. Despite the growing failure rates of small businesses (Van Eden, Viviers \& Venter, 2003) small businesses in South Africa and elsewhere continue to contribute to various economies. In South Africa, the small business sector is characterized with economic. Research showed that on average the sector generates approximately $35 \%$ of the gross domestic product (GDP), paid an estimate of $43 \%$ in employees' salaries and wages and create roughly $55 \%$ privatesector employment (Nieman et al., 2003). As such, there is the need for policy makers to reposition rural economic policies in communities to offer assistance in nurturing and mentor rural entrepreneurial output. Drawing from a plethora of academic literature on rural entrepreneurship, it therefore remains very critical that policy makers continue to investigate the impediments of entrepreneurial activities in rural areas including the NCP of South Africa to realign entrepreneurial activities with existing economic policy directives.

\section{CLASSIFICATION OF PERSONAL HURDLES}

Earlier in the survey, the author mentioned the significance of REA and its economic benefits. At the same time, it is acknowledged that in spite of these benefits, REA and the small business sector is faced with challenges. Several surveys in past have shown different hurdles that contributed to entrepreneurial failures in South Africa and the global context (Agbenyegah, 2013; Jayawarna, Jones \& Macpherson, 2011; Fatoki \& Garwe, 2010; Fang, Yuli \& Hongzhi, 2009; Arinaitwe, 2006; Scarborough \& Zimmerer, 2009). For example, a study by scholars and academics including Jayawarna et al., (2011) revealed for owner-managers and entrepreneurial activities to be successful more should be done in improving human capital skills. Most constraining factors to small business sector include lack of finance, experience, inability to use technology, lack of accounting knowledge and record keeping (Hulbert, Gilmore \& Garson, 2013; Syed, Ahmadani, Shaikh \& Shaikh, 2012; Olawalw \& Garwe, 2010; OECD, 2004).

The existing declining state of entrepreneurial activities in South Africa is a major concern. For instance, empirical evidence have shown that some of the contributory factors include deficiency in business skills and inability to access business opportunities (Herrington, Kew and Kew, 2009). Education in particular, is critical because owner-managers must be literate enough in order to access credit facilities (Ochieng \& Sije, 2013). The present surge in corrupt practices in South Africa is a cause of concern. According to Ahiwireng-Obeng and Piaray (1999), these practices increases production costs due to long negotiation periods, uncompetitive products and services; thus, reducing profit margins of owner-managers. Below are various summaries of personal hurdles (Table 1). These hurdles were divided into sections of four namely education and training, previous experience, social, resources infrastructure. In general, the owner-managers of small business experiences personal hurdles in various forms that in all influence business operations in most instances, these hurdles trigger negative impact on operations; thus, resulting in the failure of entrepreneurial activities. Aside, other demographic variables, the study is aimed to determine the contributions of personal hurdles from the perspectives of owner-managers. Even though the summary is not exhaustive the author is of the view that this survey provides enough illustrations of the main focus of this study. 
Table 1. Summary of Personal hurdles of rural entrepreneurial activities

\begin{tabular}{l|l|l|l}
\hline Education \& Training & \multicolumn{1}{|c}{ Previous experience } & \multicolumn{1}{c}{ Social } & \multicolumn{1}{c}{ Resources \& Infrastructure } \\
\hline Education \& skills & Technology & Networking & Marketing knowledge \\
\hline Business leadership & Business ownership & Information on investment & Business resources \\
\hline Seed capital funds & Sales history & Corruption, crime \& R/D & Weak market access \\
\hline Accounting knowledge & Entrepreneurship experience & Family background & No support by local government \\
\hline Human capital & Lack of confidence & High illiteracy & Source of rural energy \\
\hline & & Risk factors & Lack of permanent office \\
\hline
\end{tabular}

Source: Author's compilation from literature.

\section{Research Questions}

To what extend do resources, information, and infrastructure gaps affect business failure of owner-managers in the NCP of South Africa?

\section{Research Objectives}

To identify and understood the resources, information and infrastructure gaps that affect small businesses of ownermanagers in the NCP of South Africa

\section{SUGGESTED HYPOTHESES}

Based on scientific evidence regarding the high failure rates of small businesses in South Africa and the discussion on the personal hurdles (as divided into various gaps below) and business failures as proposed in the theoretical framework, the study hypothesize as follows:

$\mathbf{H}_{\mathbf{0}}$ : There is no significant effect of levels of resource gap on business failure.

$\mathbf{H}_{1}$ : There is a significant effect of levels of resource gap on business failure

$\mathbf{H}_{0}$ : There is no significant effect of levels of information gap on business failure

$\mathbf{H}_{\mathbf{1}}$ : There is a significant effect of levels of information gap on business failure

$\mathbf{H}_{\mathbf{0}}$ : There is no significant effect of the levels of infrastructure gap on business failure.

$\mathbf{H}_{1}$ : There is a significant effect of the levels of infrastructure gap on business failure.

\section{RESEARCH METHODOLOGY}

The study seeks to explore personal hurdles from owner-managers' perspectives. The author applied quantitative approach to collect data from owner-managers from two areas of different geographical settings in the NCP. A 7-point Likert-type scale questionnaire was designed with questions drawn from literature varying between "strongly disagree" and "strongly agree". In all 24 items were used to formulate relevant questions on the Likert scale with options. The Cronbach alpha was applied to the instrument to determine validity and reliability. Based on the cut-off value of 0.70 , only two out of 12 personal hurdles items were loaded insufficient and deleted (Kent, 2007). Majority of the 12 items used in the questionnaire have revealed values above 0.70 thus were accepted.

Owner-managers were requested to select the options according to the statements; lower scores on the scale means lack of agreement and higher scores represents agreement respectively. The Likert scale questionnaire was divided into several sections such as owner-managers educational status, business experiences, age, gender in two districts of the NCP. Equally, personal hurdles were divided into four sections of education and training, previous experience, social, resources and infrastructure. 
For more clarity, the author compiled a factor analysis as a multi-variable statistical tool to transform variables into a more comprehensive details in order to reach a conceptual layout (Rummel, 2002). In this study, factor analysis was used to determine whether personal hurdles were grouped correctly under definite factors or not (Kalayci et al., 2005). Owner-managers' responses as stated in the questionnaires were used. By means of factor analysis new elements of resources, information and infrastructure gaps were extracted from personal hurdles and applied. Other variables fell short of the criterion. Besides, indexes were calculated for options "strongly disagree to strongly agree" as stated initially on the questionnaires. Each of the indexes were converted to a categorical variable with categories ranging from low, moderate and high and applied to enhance descriptive statistics.

Distribution of questionnaires among owner-managers was on random bases. However, this was closely guided by set criteria; only owner-managers who at the time of the study operates entrepreneurial business as described and in line with small business descriptions were allowed to provide data. Also, for data accuracy, owner-managers must reside within the study areas in the NCP to participate in the study. Several data analyses methods including the descriptive methods namely the frequency and the mean techniques were employed to analyze personal hurdles. On the Likert scale questionnaires, personal hurdles (see the results of the factor analysis below) with varying statements were ranked in order of hierarchy as options for owner-managers to choose from; the mean values were calculated for data set on personal hurdles (resource, information and infrastructure) gaps. Besides, the author used the Analysis of Variance (ANOVA) to further explain relationships between variables. The Pearson correlation coefficient was used to find the relationships between the dependent; failures of rural entrepreneurship (FRE) and independent variables (resource, information and infrastructure gaps).

\section{FINDINGS AND DISCUSSION}

\section{Descriptive Statistics}

For general data dispersal, the author conducted descriptive statistics of frequency distribution and the mean as summarized in Tables 2, 3, and 4 below. The data for resource, information and infrastructure gaps were further explained for clarification.

Table 2. Resource gap

\begin{tabular}{|c|c|c|c|c|}
\hline & Frequency & Column N\% & $\mathbf{N}$ & Mean \\
\hline Low & 4 & $1.4 \%$ & 4 & 48.00 \\
\hline Moderate & 24 & $8 . \%$ & 22 & 47.82 \\
\hline High & 248 & $89.9 \%$ & 238 & 40.15 \\
\hline Total & 276 & $100.0 \%$ & 264 & 40.91 \\
\hline
\end{tabular}

The majority 248(89.9\%) of the owner-managers of small businesses experienced high resource gap with an average mean of 40.15 representing business failure index.

Table 3. Information gap

\begin{tabular}{l|c|c|c|c}
\hline & Frequency & Column N\% & N & Mean \\
\hline Low & 83 & $30.75 \%$ & 79 & 27.29 \\
\hline Moderate & 39 & $14.4 \%$ & 39 & 46.77 \\
\hline High & 148 & $54.8 \%$ & 141 & 46.98 \\
\hline Total & 270 & $100.0 \%$ & 259 & 40.93 \\
\hline
\end{tabular}

The majority 148 (54.8\%) of owner-managers experienced high information gap, which represented 46.96 average mean of business failure index. However, $83(30.75 \%)$ of the owner-managers experienced low information gap as well as low business failure index (mean=27.29). 
Table 4. Infrastructure gap

\begin{tabular}{c|c|c|c|c}
\hline & Frequency & Column N\% & N & Mean \\
\hline Low & 12 & $4.3 \%$ & 11 & 47.64 \\
\hline Moderate & 26 & $9.4 \%$ & 22 & 46.45 \\
\hline High & 239 & $86.3 \%$ & 232 & 40.16 \\
\hline Total & 277 & $100.0 \%$ & 265 & 40.99 \\
\hline
\end{tabular}

The majority 239 (86.3\%) of owner-managers experienced high infrastructure gap with an average mean of 40.16 business failure index. However, $4.3 \%$ of the owner-managers are in low infrastructure gap as well as the highest business failure index (mean=47.64).

Table 5 below revealed a high average mean of business failure index of 48.00 as the level of information gap remains low. On the other hand, a high level of information gap recorded the lowest mean average business failure index of 40.15. Moderate level of business failure index showed an average mean of 47.82 in terms of information gap.

Table 5. Resource gap

\begin{tabular}{|c|c|c|c|c|c|c|c|c|}
\hline \multicolumn{9}{|c|}{ Failures of rural entrepreneurship } \\
\hline & \multirow{2}{*}{$\mathbf{N}$} & \multirow{2}{*}{ Mean } & \multirow{2}{*}{$\begin{array}{c}\text { Std. } \\
\text { Deviation }\end{array}$} & \multirow{2}{*}{ Std. Error } & \multicolumn{2}{|c|}{ 95\% Confidence Interval for Mean } & \multirow{2}{*}{ Minimum } & \multirow{2}{*}{ Maximum } \\
\hline & & & & & Lower Bound & Upper Bound & & \\
\hline Low & 4 & 48.00 & 20.607 & 10.304 & 15.21 & 80.79 & 27 & 69 \\
\hline Moderate & 22 & 47.82 & 11.697 & 24.94 & 42.63 & 53.00 & 22 & 70 \\
\hline High & 238 & 40.15 & 17.304 & 1.122 & 37.94 & 42.36 & 17 & 77 \\
\hline Total & 264 & 40.91 & 17055 & 1.050 & 38.84 & 42.98 & 17 & 77 \\
\hline
\end{tabular}

Table 6 indicates a high average mean of 46.96 of business failure index. This is followed by a moderate resource gap yielding an average mean of 46.77 . However, there is a low 27.29 average mean of business failure index.

Table 6. ANOVA results between REF and resource gap

\begin{tabular}{|c|c|c|c|c|c|c|c|c|}
\hline \multicolumn{9}{|c|}{ Failures of rural entrepreneurship } \\
\hline & \multirow{2}{*}{$\mathbf{N}$} & \multirow{2}{*}{ Mean } & \multirow{2}{*}{$\begin{array}{c}\text { Std. } \\
\text { Deviation }\end{array}$} & \multirow{2}{*}{ Std. Error } & \multicolumn{2}{|c|}{ 95\% Confidence Interval for Mean } & \multirow{2}{*}{ Minimum } & \multirow{2}{*}{ Maximum } \\
\hline & & & & & Lower Bound & Upper Bound & & \\
\hline Low & 79 & 27.29 & 12.510 & 1.407 & 24.49 & 30.09 & 18 & 69 \\
\hline Moderate & 39 & 46.77 & 15.467 & 2.477 & 41.76 & 51.78 & 17 & 77 \\
\hline High & 141 & 46.96 & 14.787 & 1.245 & 44.50 & 49.43 & 18 & 77 \\
\hline Total & 259 & 40.93 & 16.829 & 1.046 & 38.88 & 42.99 & 17 & 77 \\
\hline
\end{tabular}

A one-way ANOVA was conducted between subjects to compare the effect level of information gap conditions. As stated in Table 7, there is a significant effect of resource gap of on REF at $\mathrm{p}<0.05$ for the two conditions. (F $(2,256)$ $=52.176, \mathrm{p}=0.05)$.

Table 7. Information gap

\begin{tabular}{l|c|c|c|c|c}
\hline \multicolumn{2}{l}{ Rural entrepreneurship failure } & & & \\
& Sum of Squares & df & Mean Square & F & Sig. \\
\hline Between Groups & 21159.835 & 2 & 10579.917 & 52.176 & 0.000 \\
\hline Within Groups & 51910.050 & 256 & 202.774 & & \\
\hline Total & 73069.884 & 258 & & & \\
\hline
\end{tabular}


Table 8. ANOVA results between FRE and information gap

\begin{tabular}{|c|c|c|c|c|c|}
\hline \multicolumn{6}{|c|}{ Rural entrepreneurship failure } \\
\hline & Sum of Squares & df & Mean Square & $\mathbf{F}$ & $\mathbf{P}$ \\
\hline Between Groups & 1387.991 & 2 & 693.995 & 2.411 & 0.092 \\
\hline Within Groups & 75115.827 & 261 & 287.800 & & \\
\hline Total & 76503.818 & 263 & & & \\
\hline
\end{tabular}

A one-way between subject's ANOVA was conducted to compare the effect of level of resource gap conditions. There is no significant effect of information gap of on REF at $\mathrm{p}>0.05$ for the two conditions. $(\mathrm{F}(2,261)=2.411, \mathrm{p}=0.092)$.

The results as shown in Table 9 depicts a low infrastructure with the largest average business index. For moderate infrastructure gaps, an average mean of 46.45 was recorded. However, for a high infrastructure gap the table indicated the lowest average business failure index with the mean of 40.16 .

Table 9. Infrastructure gap

\begin{tabular}{|c|c|c|c|c|c|c|c|c|}
\hline \multicolumn{9}{|c|}{ Rural Entrepreneurship failure } \\
\hline & \multirow{2}{*}{$\mathbf{N}$} & \multirow{2}{*}{ Mean } & \multirow{2}{*}{$\begin{array}{c}\text { Std. } \\
\text { Deviation }\end{array}$} & \multirow{2}{*}{$\begin{array}{l}\text { Std. } \\
\text { Error }\end{array}$} & \multicolumn{2}{|c|}{ 95\% Confidence Interval for Mean } & \multirow{2}{*}{ Minimum } & \multirow{2}{*}{ Maximum } \\
\hline & & & & & Lower Bound & Upper Bound & & \\
\hline Low & 11 & 47.64 & 15.015 & 4.527 & 37.55 & 57.72 & 27 & 71 \\
\hline Moderate & 22 & 46.45 & 17.126 & 3.651 & 38.86 & 54.05 & 17 & 77 \\
\hline High & 232 & 40.16 & 17.082 & 1.121 & 37.95 & 42.37 & 18 & 77 \\
\hline Total & 265 & 40.99 & 17.092 & 1.050 & 38.93 & 43.06 & 17 & 77 \\
\hline
\end{tabular}

Table 10. ANOVA results between FRE and infrastructure gap

\begin{tabular}{|c|c|c|c|c|c|}
\hline \multicolumn{6}{|c|}{ Rural entrepreneurship failure } \\
\hline & Sum of Squares & Df & Mean Square & $\mathbf{F}$ & Sig. \\
\hline Between Groups & 1302.886 & 2 & 651.443 & 2.251 & 0.107 \\
\hline Within Groups & 75817.099 & 262 & 289.378 & & \\
\hline Total & 77119.985 & 264 & & & \\
\hline
\end{tabular}

A one-way between subject's ANOVA was conducted to compare the effect of level of infrastructure gap conditions. There is no a significant effect of Infrastructure gap of on REF at $p>0.05$ for the two conditions. $(F(2,262)=2.251$, $\mathrm{p}=0.107)$

Table 11 presents the Pearson coefficients of linear correlation, depicting the relationship between the resource, information and infrastructure gaps and REF. The value of correlation coefficients on various gaps were explained. The correlation coefficient between REF and information gap is -0.092 , which suggests a low negative linear correlation between REF and information gap. The $p$-value $=0.138>0.05$ further suggests that there is no significant correlation between REF and information gap. This confirms a weak linear correlation between REF and information gap. Regarding the REF and infrastructure gap, the correlation coefficient indicates -0.045 indicating a low negative linear correlation. The $\mathrm{p}$-value $=0.465>0.05$ suggests that there is no significant correlation between REF and information gap. A correlation coefficient of 0.450 implies a positive linear correlation between REF and resource gap. The $\mathrm{p}$-value $=0.000<0.05$ suggests a significant correlation between REF and resource gap.

Table 11. Correlation coefficient matrix of resource, information and infrastructure gaps and REF

\begin{tabular}{l|l|c|c|c|c}
\hline & & $\begin{array}{c}\text { Failures of rural } \\
\text { entrepreneurship (REF) }\end{array}$ & $\begin{array}{c}\text { Resource gap } \\
\text { index }\end{array}$ & $\begin{array}{c}\text { Information gap } \\
\text { index }\end{array}$ & $\begin{array}{c}\text { Infrastructure gap } \\
\text { index }\end{array}$ \\
\hline $\begin{array}{l}\text { Failures of rural } \\
\text { entrepreneurship } \\
\text { (REF) }\end{array}$ & Pearson Correlation & 1 & $.450^{* *}$ & -.092 & -.045 \\
\hline & P-value & & 0.000 & 0.138 & 0.465 \\
\hline & $\mathrm{N}$ & 270 & 259 & 264 & 269 \\
\hline
\end{tabular}

** Correlation is significant at the 0.01 level (2-tailed). 


\section{TESTING THE HYPOTHESES}

The Pearson's correlation coefficient was conducted to approve or disapprove relationships between the dependent variables (REF) and independent variables (the different gaps). Reasons to accept or reject each formulated hypothesis hinge on the significance of the p-value. Essentially at a 5\% level of confidence; if $p<0.05$ the null hypothesis is rejected. Drawing from the outcomes of the applicable technique used (ANOVA), there were mixed findings regarding different (resource, information and infrastructure) aps. Table 5 showed a $5 \%$ level of evidence to suggest that there is significant effect of resource gap on REF; hence the stated hypothesis $\mathrm{H}_{0}$ is rejected. From Table 7, the $\mathrm{H}_{0}$ is not rejected as the statistics proof indicated a rather insufficient evidence at $5 \%$ level of significance to suggest the effect of information gap on REF. Similarly, Table 9 have shown that $\mathrm{H}_{0}$ is not rejected because there is no sufficient evidence to suggest the effect of infrastructure gaps on REF.

\section{CONTRIBUTIONS, RECOMMENDATIONS AND IMPLICATIONS OF THE STUDY}

The current study is based on empirical views of owner-managers. Simply put, the author through the findings of this survey provided additional scientific knowledge to existing rural entrepreneurship theory. Thus, this study does not only showed practical benefits to owner-managers, but also towards the survival of rural entrepreneurial activities. Recommendations from this survey are geared towards growing rural entrepreneurship.

The role of government especially the provincial authorities must be increased. More is expected from the provincial authorities regarding entrepreneurial education, encourage entrepreneurial culture through adequate training in various skills. In order to lessen some of the problems, owner-managers should be given tailored-made training initiatives that can easily address specific needs of particular rural communities. The training requirements of owner-managers should not be generic as rural areas differs in their approach to entrepreneurial activities. Government agencies in rural areas need to provide specific strategies to address the problems of high rate of rural entrepreneurship failure. This must be done in partnership with owner-managers from rural communities. Personal problems (PPs) as well as business and operational problems (BOPs) can only be addressed provided all role players are included in decision-making. Rural awareness campaigns (RACs) should be encouraged by the provincial authorities through various platforms such as community radio stations in local languages. Through these campaigns, owner-managers can access enough information about funding and marketing issues among others.

Key recommendations to owner-managers include; the formation of rural networks, partnership with provincial authorities including the financial institutions, RACs, the formulation of rural entrepreneurship strategies (RESs) to address only problems of rural small businesses (RSBs). The provincial authorities need to establish specialized ruraleconomic zones (SREZs) aim at providing preferential treatment for owner-managers through integrated regulatory framework.

According to the survey outcomes, REA continue to fail due to PPs and BOPs mostly in rural communities of South Africa. The general concern by the provincial authorities is to encourage owner-managers of small businesses in order to create jobs and reduce unemployment and poverty. In order to increase survival rates of REA entrepreneurial activities in South Africa, owner-managers must go through specific policy measures and entrepreneurship programs such as entrepreneurship education, mentorship programs and coaching by community role models. The provincial government must initiate long-term action policies to increase owner-mangers confidence levels among rural communities. In addition, the provincial government need to establish socio-cultural policies that reduces the existing pressures of "fear of failure" on communities that stifle entrepreneurial activities. Particular policy measures must be initiated by government to look into existing costs of doing business in rural communities.

\section{LIMITATIONS AND FUTURE RESEARCH}

The present survey provides enormous benefits to owner-managers of rural small businesses. In spite of these benefits, this survey is without shortcomings. At the core of the limitations is the fact that the survey took place in two disadvantaged areas in the NCP of South Africa. The survey would have been more insightful besides socio-economic advantages to wider rural communities across the country. In summary, future rural survey should broaden the research scope to include other rural localities to allow for comparison studies of entrepreneurship across other rural settings 
countrywide. Finally, it would be more beneficial to apply mixed research method in order to better understand the challenges of rural owner-managers of small businesses. Applying mixed method would provide more robust findings and contribute to the present scientific theory on rural entrepreneurial activities.

\section{ECONOMIC IMPLICATIONS}

Drawing from plethora of existing literature on rural entrepreneurial activities and its impact on economic contributions, the major implications are as follows:

- Without doubt, entrepreneurial activities play significant role in emerging economies including South Africa.

- Though the bulk of entrepreneurial domain according to available literature remains poor with sporadic high failure rates due to multitude of challenges, still much is contributed as indicated in the study to the economy in numerous ways.

- These economic benefits through entrepreneurial activities, implies that given the relevant education and training, support systems and infrastructure, owner-managers across rural economies of South Africa can immensely contribute to rural economic success.

- Key economic implications can therefore eminent from employment generation, provision of household income as individuals become employable and poverty remains minimal.

\section{CONCLUSION}

This survey examined personal hurdles namely resources, information and infrastructure gaps as contributors to REA. Small businesses and entrepreneurial failure in general have for years been the subject of discussion among academics and researchers. Though all the gaps examined during the survey somehow affect REA in general, the resource gaps as evident in this study have displayed a very low rate during the survey. As expected in rural areas, infrastructure gap severely affect REA. This findings imply that rural communities need infrastructure overhaul to stimulate entrepreneurial activities and halt small business failure. There is the need for provincial authorities to make available not only facilities to enable owner-managers to access business information, but also to make sure the right facilities are in place. Providing adequate resources such as more access to funding is vital in operating successful entrepreneurial activities. Inadequate funding has been documented as potential contributor to the general failure of entrepreneurial activities. Simply stated, resource gaps according to available literature highly affect REA in a negative way. Finally, it can be stated that all the gaps namely resource, information and infrastructure in a way contribute to REF. As such, much effort by the provincial authorities is required as an enhancement tool to change the present state of high failure of REA. These gaps according to the study, are the main hurdles that confronts owner-managers.

\section{AUTHOR BIOGRAPHIES}

Albert Tchey Agbenyegah, Ph.D, obtained his MBA degree in 2003 had further education in UNISA where he graduated with honors in tax strategy. In 2013, he completed his PhD (Business Administration) at the North West University, Potchefstroom. As an emerging researcher, his research passion includes rural entrepreneurship and small businesses, technology education, business and strategic management. Email: alberta@dut.ac.za

Dr. Bongani Innocent Dlamini Ph.D, is a senior lecturer (HOD), Department of applied Management Sciences, Durban University of Technology (DUT), Riverside Campus. Bongani's area of research are business environment, human relations and entrepreneurship education. Email: dlamini@dut.ac.za 


\section{REFERENCES}

Abor, J. \& Quartey, P. (2010). Issues in SME development in Ghana and South Africa. International Research Journal of Finance and Economics. [Online]. Available:

http://www.smmeresearch.co.za/SMME\%20Research\%20General/Journal\%20Articles/Issues\%20in\%20SME\%20devel opment\%20in\%20Ghana\%20and\%20SA.pdf [Accessed: April 30, 2017].

Agbenyegah, A.T. (2013). Challenges facing rural entrepreneurship in selected areas in South Africa. PhD thesis, Business Administration. North West University.

Ahamad, T. \& Pandey, J. K. (2015). A study on development of rural areas through industries in India. International Journal of Applied Research, 1(4), 1-4.

Ahwireng-Obeng, F. \& Piaray, D. (1999). Institutional obstacles to South African entrepreneurship. South African Journal of Business Management, 30(3),78-98.

Ahmad, N. H. \& Seet, P. S. (2009). Dissecting behaviours associated with business failure: a qualitative study of SME owners in Malaysia and Australia. Asian Social Science, 5(9), 98.

Arinaitwe, J. K. (2006). Factors Constraining the Growth and Survival of Small Scale Businesses. A Developing Countries Analysis, Journal of American Academy of Business, 8(2),167-178.

Aldrich, H. E., Martinez, M. A. (2001). Many are called, but few are chosen: An evolutionary perspective for the study of entrepreneurship. Enterp. Theory Pract. 25(4), 41-56.

Armstrong, C. \& Shimizu, K. (2007). A review of approaches to empirical research on the resource-based view of the firm. Journal of Management, 33(6), 959-986.

Ayyagari, M., Demirguc-Kunt, A. \& Maksimovic, V. (2011). Small vs. Young firms across the world contribution to employment, job creation, and growth. Policy Research Working Paper 5631. The World Bank Development Research Group Finance and Private Sector Development Team 2011.

Bad, P., Patel, V. \& Tare, D. (2013). Rural Entrepreneurship. (Online). Available at: http:/www.scrib.com/doc/27594118/Ruralentrepreneurship. (Accessed: 12 July 2017).

Barmon, R. \& Chakraborty, D. (2013). Rural entrepreneurship one - Key to rural revitalization. Research Paper Commerce, 3(5).

Baumgartner, D., Schulz, T. \& Seidl, I. (2013). Quantifying entrepreneurship and its impact on local economic performance: A spatial assessment in rural Switzerland. Entrepreneurship \& Regional Development, 25(3-4), 222-250

Benedikter, S., Waibel, G. \& Birtel, S. (2013). Local entrepreneurship in Vietnam's rural transformation. A case study from the Mekong Delta. (Online) Available at: http://mpra.ub.unimuenchen.de/49866/1/MPRA_paper_49866.pdf (Accessed: 15 March 2017).

Bosworth, G. (2012). EU industrial policy and competitiveness in rural SMEs. International Journal of Entrepreneurship and Small Business, 14(3), 391-40

Brink, A., Cant, M. \& Ligthelm, A. (2003). Problems experienced by small businesses in South Africa. $\mathrm{http}: / / w w w . c c c . c a n . a u /$ programs/rersources-manager/accounts/seanz-papers/newdocant.pdf

Brown, D. L. \& Schafft, K. A. (2011). Rural people and communities in the 21st century: Resilience \& transformation. Cambridge: Polity Press.

Cant, C. \& Wiid, J. (2013). Establishing the challenges affecting South African SMEs'. International Business Economics Research Journal, 12(6), 707-716.

Chun, N. \& Watanabe, M. (2012). Can skill diversification improve welfare in rural areas? Evidence from Bhutan. Journal of Development Effectiveness, 4(2), 214-234.

Colette, H. \& McElwee, G. (2014). Defining and conceptualising rural enterprise, in Colette.

Cravo, T. A., Gourlay, A. \& Becker, B. (2012). SMEs and regional economic growth in Brazil. Small Business Economics, 38(2), 217-230.

Deakins, D. \& Freel, M. (1998). Entrepreneurial learning and the growth process in SMEs. The Learning Organization, 5(3): 144-155.

Diochon, M. C. (2003). Entrepreneurship and Community Economic Development. McGill-Queen's University Press: Montreal, Quebec.

Duarte, N. \& Diniz, F. (2011). The role of firms and entrepreneurship on local development. Romanian Journal of Regional Science, 5(1), 54-69.

Durr, M., Lyons, T. S. \& Lichtenstein, G. A. (2000). Identifying the unique needs of urban entrepreneurs: African American skill set development. Race and Society, 3, 75-90.

EU Rural Review. (2011). EU Rural Review: The magazine from the European Network for Rural Development. [Online]. Available at: http://enrd.ec.europa.eu/enrdstatic/fms/pdf/ED5808AC-994A-47AD-928F- 0D3088716910.pdf (Accessed 23 May 2017).

European Commission (2013). Communication from the commission to the European Parliament, the council, the European economic and social Committee of the regions. Entrepreneurship 2020 Action Plan. COM (2012), 795 final.

Fang, N., Yuli, Z. \& Hongzhi, X. (2009). Acquisition of resources, formal organization and entrepreneurial orientation of new ventures, Journal of Chinese Entrepreneurship, 1(1), 40-52. 
Fatoki, O. O. (2011). Impact of human social and financial capital on the performance of small and medium sized enterprises (SMEs) in South Africa; Journal of Social Sciences, 9(3), 193-204.

Fatoki, O. O. \& Asah, F. (2011). The impact of firm and entrepreneurial characteristics on access to debt finance by SMEs in King Williams' Town, South Africa. International Journal of Business and Management, 6(8), 170.

Fatoki, O. \& Garwe, D. (2010). Obstacles to the growth of new SMEs in South Africa: A principal component analysis approach, African Journal of Business Management, 4(5), 729-738.

Ferrao, J. \& Lopes, R. (2004). Understanding Peripheral Rural Areas as Contexts for Economic Development, in L. Labrianidis (ed.), The Future of Europe's Rural Peripheries, Ashgate: Aldershot and Burlington.

Frederick, H. (2007). Asia-Pacific teaching and research in entrepreneurship. http://www.ten3.biz/learning/mod/resource/view.php?id=814 (Accessed 4 July 2017).

Fuller-Love, N., Midmore, P. \& Thomas, D. (2006). Entrepreneurship and rural economic development: a scenario analysis approach. International Journal of Entrepreneurial Behaviour and Research, 12(5), 289-305.

Gideon, L. (2012). Handbook of survey methodology for the social sciences. New York: Springer.

Gitman, L. J. (2009). Principles of managerial finance. 12th ed. Cape Town:Paerson/Prentice Hall South Africa.

Herrington, M. Kew, J. \& Kew, P. (2009). Tracking entrepreneurship in South Africa: a GEM perspective [Online]. Available: http//www.gemconsortium.org/article (6 July 2017)

Hisrich, R. D. \& Peters, M. P. (2002). Entrepreneurship. 5th ed. New York, NY: McGraw-Hill.

Hulbert, B., Gilmore, A. \& Carson, D. (2013). Sources of opportunities used by growth minded owner managers of small and medium sized enterprises. International Business Review, 22(1), 293-303.

Jayawarna, D., Jones, O. \& Macpherson, A. (2011). New business creation and regional development: Enhancing resource acquisition in areas of social deprivation. Entrepreneurship and Regional Development, 23(9-10), 735-761.

Karjalainen, K. \& Kemppainen, K. (2008) The involvement of small and medium-sized enterprises in public procurement: Impact of resource perceptions, electronic systems and enterprise size. Journal of Purchasing and Supply Management $14,230-40$

Kalantaridis, C. \& Bika, Z. (2011): Entrepreneurship origin and the configuration of innovation in rural areas: The case of Cumbria, North West England. Environment and Planning A, 43(4), 866-884.

Kalayci, S., Albayrak, A. S., Eroğlu, A., Küçüksille, E., Ak, B., Karaalti, M., Ke. \& Sungur, O. (2005). SPSS Applied Multivariate Statistical Techniques. Asil Publication 1. Edition Ankara.

Kent, R. (2007). Marketing research approaches, methods, and applications in Europe. London: Thomson Learning.

Khalique, M., Isa, A. H. B. M., Shaari, N. \& Abdul, J. (2011). Challenges for Pakistani SMEs in a Knowledge-Based Economy. Industry Journal of Management \& Social Sciences, 5(2).

Korsgaard, S. \& Müller, S. (2015). Rural entrepreneurship or entrepreneurship in the rural - between place and space. International Journal of Entrepreneurial Behavior \& Research, 21(1),1-17.

Labrianidis, L. (2006). Fostering entrepreneurship as a means to overcome barriers to development of rural peripheral areas in Europe. European Planning Studies, 14(1), 3-8.

Lehmann, U., Dieleman, M. \& Martineau, T. (2008). Staffing remote rural areas in middle- and low-income countries: A literature review of attraction and retention. BMC Health Services Research, 8(1), 19.

Lussier, R. N. (1996). A business success versus failure prediction model for service industries. Journal of Business and Entrepreneurship, 8(2), 23-37.

Meccheri, N. \& Pelloni, G. (2006). Rural entrepreneurs and institutional assistance: an empirical study from mountainous Italy: Entrepreneurship \& Regional Development: An International Journal, 18(5), 371-392.

Mochrie, R., \& Galloway, L. (2004). Proceedings of the Agriculture Economics Society 78th Annual Conference, London: Motivations for business start-up in Scotland.

Nieman, G., Hough, J. \& Niewenhuizen, C. (2003). Entrepreneurship. Pretoria: Van Schaik.

North, D. \& Smallborne, D. (2006). Developing entrepreneurship and enterprise in Europe's peripheral rural areas: Some issues facing policy-makers. European planning studies, 14(1), 41-61.

Njiro, E. \& Compagnoni, M. (2010). Institutions providing financial services to small, micro and medium enterprises in South Africa. Journal of Contemporary Management, 7, 146-166.

Ochieng, P. A. \& Sije. A. (2013). Strategy adoption and women entrepreneurs in accessing credit facilities in Kenyan financial institutions a case of women entrepreneurs in Komla municipality, Kisumu Country. International Journal of Small Business and Entrepreneurship Research, 1(4), 1-10.

OECD. (2004). Conference Proceedings of Second OECD Conference of Ministers responsible for Small and Medium-sized Enterprises SMEs: Promoting Entrepreneurship and innovative SMEs in a global economy. Available at: http://www.oecd.org/cfe/smes/31919590.pdf. Accessed: 17 July 2017

Olawale, F. \& Garwe, D. (2010). Obstacles to the growth of new SMMEs in South Africa: A principal component analysis approach. African Journal of Business Management, 4(5), 729-738.

Penrose, E. (1980). The Growth of the Firm. New York: M.E. Sharpe

Petrin, T. \& Gannon, A. (1997). Rural development through entrepreneurship (Rome: FAO) Pezzini, M. (2001) Rural policy lessons from OECD countries. International Regional Science Review, 24(1), 134-145. 
Republic of South Africa (RSA) (1995). National strategy for the development and promotion of small businesses in South Africa. White Paper: Government Gazette, 357 (16317) 20 March.

Rogoff, E. G., Lee, M. S. \& Suh, D. C. (2004). "Who Done It?” Attributions by entrepreneurs and experts of the factors that cause and impede small business success. Journal of Small Business Management, 42(4), 364-376.

Rummel, R. J. (2002). Understanding factor analysis. University of Hawaii, Aloha, 3-20

Saxena, S. (2012). Problems faced by rural entrepreneurs and remedies to solve it. IOSR Journal of Business and Management (IOSRJBM), 3(1), 23-29.

Scarborough, N. M., Wilson, D. L. \& Zimmerer, T. W. (2009). Effective small business management. 9th Ed. New Jersey: Pearson Education, Inc. Upper Saddle River.

Siemens, L. (2010). Challenges, responses and available resources: Success in rural small businesses. Journal of Small Business and Entrepreneurship, 23(1), 65-80.

Smallbone, D., North, D., Baldock, R. \& Ekanem, I. (2002). Encouraging and supporting rural enterprise. RR-RS009/02, Small Business Service, Kingsgate House, 66-74 Victoria Street, London SW1E 6SW.

Stathopoulou, S., Psaltopoulos, D. \& Skuras, D. (2004). Rural entrepreneurship in Europe. A research framework and agenda. Journal of Entrepreneurial Behaviour \& Research, 10(6), 404-425

Stokes, D. \& Blackburn, R. (2002). Learning the hard way: The lessons of owner-managers who have closed their businesses. Journal of Small Business and Enterprise Development, 9(1), 17-27.

Syed, A. A. S. G., Ahmadani, M. M., Shaikh, N. \& Shaikh, F. M. (2012). Impact analysis of SMEs sector in economic development of Pakistan: A case of Sindh. Journal of Asian Business Strategy, 2(2, 44-53.

Temtime, Z.T. \& Pansiri, J. (2004). Small business critical success/failure factors in developing economies: Some evidence from Botswana. American Journal of Applied Sciences, 1(1), 18-25.

Van Eeden, S., Viviers, S. \& Venter, D. 2003. A comparative study of selected problems encountered by small businesses in the Nelson Mandela, Cape Town and Egoli metropoles. Management Dynamics, 12(3), 13-23.

Van Vuuren, J.J. \& Groenewald, D. (2007). A critical analysis of the influence of start-up factors in small business Entrepreneurial ventures in South Africa. Acta Commerci.

Vaillant, Y. \& Lafuente, E. (2007). Do different institutional frameworks condition the influence of local fear of failure and entrepreneurial examples over entrepreneurial activity? Entrepreneurship and Regional Development, 19(4), $313-337$.

Von Broembsen, M., Wood, E. \& Herrington, M. (2005). Global Entrepreneurship Monitor, South African Report. Online: From http://www.gbs.nct.ac.za/gbswebb/userfiles/gemsouthafrica2000pdf > Retrieved on 20 June 2017.

Werlen, R. R. R. (2007). An overview of ICT innovation for developmental projects in marginalized rural areas. [Online] Available at: http://ekhayaict.com/eKhayaICT4D.pdf [Accessed May 2017].

Wink, R. (2008). Gatekeepers and proximity in science-driven sectors in Europe and Asia: The case of human embryonic stem cell research. Regional Studies, 42(6), 777-791.

Wortman, M. S., Jr. (1990). Rural entrepreneurship research: an integration into the entrepreneurship field. Agribusiness, 6(4), 329-344.

Zacharakis, A. L., Meyer, G. D. \& De Castro, J. (1999). Differing perceptions of new venture failure: a matched exploratory study of venture capitalists and entrepreneurs. Journal of Small Business Management, 37(3), 1. 